\title{
MENTORI - OKOSNICA PRAKTIČNE PODUKE STUDENATA BIBLIOTEKARSTVA FILOZOFSKOG FAKULTETA U ZAGREBU
}

\author{
MENTORS - THE PILLARS OF PRACTICAL \\ EDUCATION OF LIBRARY SCIENCE STUDENTS \\ AT THE FACULTY OF HUMANITIES AND SOCIAL \\ SCIENCES IN ZAGREB
}

\author{
Dorja Mučnjak \\ Filozofski fakultet \\ Sveučilište u Zagrebu \\ dmucnjak@ffzg.hr \\ Jadranka Lisek \\ Fakultet elektrotehnike i računarstva \\ Sveučilište u Zagrebu \\ jadranka.lisek@fer.hr
}

UDK / UDC 02:378.147-057.87

Izvorni znanstveni rad / Original scientific paper

Primljeno / Received: 18. 9. 2018.

Prihvaćeno / Accepted: 9. 10. 2018.

\section{Sažetak}

Cilj. Cilj ovog istraživanja bio je da se na uzorku studenata na studentskoj praksi i knjižničara/mentora utvrdi postoje li razlike među njihovim stavovima o važnosti studentske prakse, kompetencijama koje studenti usvajaju na praksi te osobinama i kompetencijama mentora.

Vjesnik bibliotekara Hrvatske 61, 2(2018), 155-177

ISSN 0507-1925

(C) VBH 2018. 
Metodologija. U istraživanju su sudjelovale dvije skupine ispitanika: studenti 2. godine diplomskog studija bibliotekarstva na Odsjeku za informacijske i komunikacijske znanosti pri Filozofskom fakultetu Sveučilišta u Zagrebu i knjižničari Knjižnice Filozofskog fakulteta Sveučilišta u Zagrebu. Korištena je kvalitativna metodologija polustrukturiranih dubinskih intervjua za studente i fokus-grupe za knjižničare.

Rezultati. Rezultati su pokazali da obje skupine ispitanika smatraju kako je studentska praksa važna iz ovih razloga: praksa je mjesto upoznavanja studenata s knjižnicom i knjižničarskim poslom, ona je nadopuna studijskom programu te daje uvid u organizacijsku kulturu ustanove. Studenti prednost daju usvajanju generičkih kompetencija (osobito komunikacijske vještine) na praksi, dok knjižničari naglašavaju važnost usvajanja stručnih vještina. Obje skupine navode da su stručne kompetencije mentora važne, ali daju prednost njegovim vrlo razvijenim generičkim vještinama, osobito komunikacijskim vještinama (interpersonalnim i intrapersonalnim vještinama).

Ograničenja. U istraživanju su sudjelovali samo knjižničari iz Knjižnice Filozofskog fakulteta Sveučilišta u Zagrebu pa se preporučuje provjera mogućnosti generalizacije istraživanja na uzorcima knjižničara/mentora iz drugih vrsta knjižnica.

Praktična primjena. Rezultati ovog istraživanja mogu biti temelj za osmišljavanje poučavanja knjižničara/mentora.

Originalnost. Ovo istraživanje prvo u Hrvatskoj na ovakav način istražuje važnost studentske prakse, kao i to koje kompetencije studenti na praksi usvajaju te koje kompetencije mentor mora imati da bi bio kvalitetan mentor.

Ključne riječi: knjižnice, kompetencije, mentoriranje, studentska praksa

\begin{abstract}
Goal. The goal of this research was to determine, on a sample of students in practical training and librarians/mentors, the differences between their attitudes about the importance of practical training, the competences that the students acquire in practical training, and the characteristics and competences of the mentors.

Methodology. Two groups of examinees participated in the research: the second year undergraduate students of library science at the Department of Information and Communication Sciences at the Faculty of Humanities and Social Sciences of the University of Zagreb and the librarians of the Library of the Faculty of Humanities and Social Sciences of the University of Zagreb. The qualitative research methods were used, including the semi-structured in-depth interviews of the students and the focus groups for the librarians.
\end{abstract}


Results. The results showed that both groups of examinees considered student practical training important for the following reasons: a practical training is where students are being introduced to libraries and librarianship, it is complementary to a study program and provides an insight into the organizational culture of the institution.

The students prefer the acquiring of generic competences (especially communication skills) in practical training, while the librarians emphasize the importance of acquiring professional skills. Both groups believe that the professional competences of a mentor are important, but express preference for a mentor's highly developed generic skills, particularly communication skills (interpersonal and intrapersonal skills).

Limitations. Only the librarians from the Library of the Faculty of Humanities and Social Sciences of the University of Zagreb participated in the research. It is recommended to examine the possible generalization of the research using samples of librarians/mentors from other types of libraries.

Practical use. The research results could set the grounds for designing a model of librarian/mentor education.

Originality. The research is the first of this kind conducted in Croatia, exploring, in this manner, the importance of student practical training, the competences students acquire during practical training as well the competences that make a good mentor.

Keywords: libraries, competences, mentoring, student practical training

\section{Uvod}

Biti mentor ${ }^{1}$ studentima koji se obrazuju za posao u knjižnici ${ }^{2}$ za knjižničara predstavlja poseban izazov. Odgovornost za taj položaj važna je zbog toga što je studentska praksa prvi formalni susret studenta sa svakodnevnim poslom knjižničara. Mentor je u tome odnosu iskusnija i obrazovanija osoba koja svoje znanje i iskustvo prenosi na osobu koja će uskoro doći na tržište rada.

$\mathrm{Na}$ Odsjeku za informacijske i komunikacijske znanosti pri Filozofskom fakultetu Sveučilišta u Zagrebu studenti na preddiplomskoj razini studija informacijskih znanosti i diplomskoj razini studija informacijskih znanosti, smjer biblio-

\footnotetext{
1 Izrazi koji se koriste u ovom radu, a imaju rodno značenje, rodno su neutralni i koriste se za oba roda.

2 U Hrvatskoj studijski programi na kojima se obrazuju budući knjižničari imaju različite nazive: u Zagrebu na preddiplomskoj razini studenti upisuju Studij informacijskih znanosti, a na diplomskoj razini Informacijske znanosti, smjer bibliotekarstvo; na Filozofskom fakultetu u Osijeku studenti na obje razine studiraju Informatologiju, a u Zadru Informacijske znanosti.
} 
tekarstvo ${ }^{3}$, imaju obvezu odraditi studentsku praksu. Zagrebačke knjižnice koje su sudjelovale u provođenju studentske prakse u akad. god. 2017./2018. ${ }^{4}$ jesu: Knjižnica Filozofskog fakulteta Sveučilišta u Zagrebu, Nacionalna i sveučilišna knjižnica u Zagrebu, Knjižnice grada Zagreba, Knjižnica Hrvatske akademije znanosti i umjetnosti, Hrvatska knjižnica za slijepe, Centar za znanstvene informacije IRB-a i Knjižnica Instituta za etnologiju i folkloristiku. ${ }^{5}$ Na preddiplomskoj razini studentska praksa traje 40 sati za studente dvopredmetnih studija, a 80 sati za studente jednopredmetnog studija. ${ }^{6}$ Studenti moraju odraditi praksu, ali nije nužno da praksu odrade u knjižnici, nego mogu odabrati neku drugu informacijsku ustanovu. Na diplomskoj razini studenti moraju odraditi 160 sati. $^{7}$ Od toga 120 sati prakse moraju odraditi u tri knjižnice: Knjižnici Filozofskog fakulteta Sveučilišta u Zagrebu, Nacionalnoj i sveučilišnoj knjižnici u Zagrebu i Knjižnicama grada Zagreba, u svakoj po 40 sati. Četvrtu knjižnicu mogu birati.

Kroz Knjižnicu Filozofskog fakulteta Sveučilišta u Zagrebu u ljetnom semestru (kada studenti obično odrađuju praksu) prođe 50-ak studenata s preddiplomske i diplomske razine studija. Zbog znatnog opterećenja mentori su svi predmetni stručnjaci - voditelji predmetnih zbirki i djelatnici zajedničkih službi. Mentorskih dužnosti oslobođeni su informatičar (sistemski knjižničar), administrativna službenica i voditeljica. Po stručnim zvanjima, u održavanju prakse sudjeluju pomoćni, diplomirani i viši knjižničari te knjižničarski savjetnici.

S obzirom na različita iskustva, godine staža, osobne, stručne i generičke kompetencije mentora, postavlja se pitanje kakav bi mentor trebao biti te koja bi znanja, opća i specifična, trebao prenijeti na studenta, odnosno koje bi kompetencije kod studenta trebao razviti.

\footnotetext{
3 Tijekom devedesetih godina 20. stoljeća došlo je do promjene nazivlja u knjižničarstvu. Dotadašnja izvedenica međunarodnog termina bibliotekar/bibliotekarstvo ostala je u uporabi na zagrebačkom studiju bibliotekarstva i u naslovu Vjesnika bibliotekara Hrvatske, dok je u struci i zakonodavstvu prevladao naziv knjižničar/knjižničarstvo.

4 Filozofski fakultet Sveučilišta u Zagrebu. Odluka od 27. studenog 2017. Klasa: 112-04/1703/29, Urbroj: 3804-460-17-2.

5 Prethodnih godina u provođenju prakse sudjelovala je i Središnja knjižnica Fakulteta elektrotehnike i računarstva Sveučilišta u Zagrebu.

6 Studentska praksa - preddiplomski studij. [citirano: 2018-08-18]. Dostupno na: http://inf.ffzg. unizg.hr/index.php/hr/studij/preddiplomski-studij/studentska-praksa.

7 Studentska praksa - diplomski studij. [citirano: 2018-08-18] Dostupno na: http://inf.ffzg.unizg. hr/index.php/hr/studij/diplomski-studij/studentska-praksa.
} 


\section{Pregled literature}

Obilje tekstova na temu mentorstva ukazuje na globalnu raširenost $\left(\mathrm{SAD}^{8}, \mathrm{Ka}-\right.$ nada $^{9}$, Australija ${ }^{10}$, Europa ${ }^{11}$, Daleki istok ${ }^{12}$ ) promišljanja o studentskoj praksi kao važnoj sastavnici formalnog obrazovanja. Iako, za razliku od zagrebačkog studija, svi obrazovni sustavi nisu usvojili studentsku praksu kao obveznu, oni ne negiraju njezinu važnost. Upravo zbog toga u anglo-američkoj strukovnoj zajednici provode se istraživanja kako bi se dokazala važnost prakse u formalnom obrazovanju s obzirom na to da ona nije njegov obvezan dio. ${ }^{13}$ Zanimljiv je i trend održavanja prakse za preddiplomske studente raznih smjerova ${ }^{14}$ kako bi se oni mogli odlučiti odgovara li im uopće nastavak studija u području knjižničarstva i općenito rad u knjižnici. Literatura potvrđuje da je u uređenim zapadnim društvima, osobito na sjeveru Europe ${ }^{15}$,

8 Stone, C. B.; A. M. Gruber. Ambitious student seeks valuable internship: will you mentor me? // LOEX Conference Proceedings 2011, 3(2013), 11-14. [citirano: 2018-07-12]. Dostupno na: http://commons.emich.edu/loexconf2011/3; Hussey, L. K.; J. Campbell-Meier. Is there a mentoring culture within the LIS profession? // Journal of Library Administration 57, 5(2017), 500-516. DOI: $10.1080 / 01930826.2017 .1326723$.

9 Henshilwood, A.; C. Sewerin; M. Spence; T. Zahradnik. Librarians: the next generation: mentorship at the University of Toronto. // 122nd ASEE Annual Conference \& Exposition, Seattle, USA, June 14-17, 2015. DOI: 10.18260/p.24433; Harrington, M.; E. Marshall. Analyses of mentoring expectations, activities, and support in Canadian academic libraries. // College \& Research Libraries 75(2014), 763-790. DOI: 10.5860/crl.75.6.763.

10 Pymm, B.; P. Juznic. The view from industry: LIS students on placement. // Library Review 63, 8/9(2014), 606-623. DOI: 10.1108/LR-01-2014-0013.

11 Lang, U. Being a mentor : [izlaganje]. // IFLA WLIC 2015 - Cape Town, South Africa - Satellite Meeting: Continuing Professional Development and Workplace Learning Section. Taking Charge of your LIS Career: Personal Strategies, Institutional Programs, Strong Libraries, 12-14 August 2015, City of Cape Town, South Africa. [citirano: 2018-08-18]. Dostupno na: http://library.ifla.org/id/ eprint/1940; Toivonen, L.; S. Pitkakoski; P. Hynninen. Mentoring LIS students during their internships: case study: [izlaganje] // IFLA WLIC 2017 - Wrocław, Poland - Libraries. Solidarity. Society. School Libraries, Education and Training and Continuing Professional Development and Workplace Learning. [citirano: 2018-08-18]. Dostupno na: http://library.ifla.org/id/eprint/1645.

12 Ho, K.; P. Lo; D. Chiu; E. Wei San Kong; J. Chao-chen Chen; Q. Zhou; Y. Xu; S. Dalsgard. Intrinsic vs. extrinsic motivations of Master of Library and Information Science students: a cross-cultural comparative study. // Journal of Librarianship and Information Science 50, 2(2017), 141-156. DOI: 10.1177/0961000616664564.

13 Lacy, M.; A. J. Copeland. The role of mentorship programs in LIS education and in professional development. // Journal of Education for Library and Information Science 54, 2(2013), 135-146. [citirano: 2018-06-23]. Dostupno na: http://www.jstor.org/stable/43686941; Stone, C. B.; A. M. Gruber. Nav. dj.

14 Lamb, C.; B. Hendricks; Q. D. Galbraith. Growing the profession: mentoring undergraduates for librarianship. // College \& Undergraduate Libraries 22, 2(2015), 123-148. DOI: 10.1080/10691316.2015.1035181; Campbell-Meier, J.; L. K: Hussey. Learning outcomes for student workers? Perceived mentoring and the gap between training and educating library student workers. // The Journal of Academic Librarianship 42, 6(2016), 745-749. DOI: 10.1016/j. acalib.2016.06.007.

15 Toivonen, L.; S. Pitkakoski; P. Hynninen. Nav. dj.; Ho, K.; P. Lo; D. Chiu; E. Wei San Kong; J. Chao-chen Chen; Q. Zhou; Y. Xu; S. Dalsgard. Nav. dj. 
za odabir struke intrinzična motivacija važnija od ekstrinzične, pa su programi prakse prije odabira diplomske razine studija dobra prigoda da osoba izabere želi li se razvijati u knjižničarstvu ili ne.

Autori navode nekoliko glavnih razloga zbog kojih je praksa važna:

1. premošćuje se jaz između teorije naučene na studiju i svakodnevnog praktičnog rada u knjižnici ${ }^{16}$

2. potiče se samopouzdanje ${ }^{17} \mathrm{i}$ psihosocijalno razumijevanje položaja mladog stručnjaka unutar struke ${ }^{18}$

3. upoznaje se studente s organizacijskom kulturom ${ }^{19}$

4. pokazuje se stvarna slika knjižničarskog posla. ${ }^{20}$

Što se tiče kompetencija koje studenti razvijaju na praksi, mnogi autori stavljaju naglasak na razvoj kompetencija važnih za odgovaranje na informacijske upite i druge potrebe korisnika (socijalne i komunikacijske vještine) te poduku informacijske pismenosti, a slijede ih kompetencije važne za razvoj i održavanje digitalnih zbirki kao što su nabava, vještina pregovaranja, poznavanje koncepata autorskog prava... ${ }^{21} \mathrm{Od}$ ostalih kompetencija koje su studenti razvijali na praksi, autori navode i katalogizaciju ${ }^{22}$, nabavu i poslovanje. ${ }^{23}$ Bitnim se pokazalo to da studenti rade više različitih poslova te ono što ih zanima. ${ }^{24}$ Kako bi suradnja knjižnice i fakulteta bila što uspješnija u razvoju vještina studenata na praksi, važna je dobra međusobna komunikacija te knjižničarevo poznavanje studijskog programa. ${ }^{25}$

\footnotetext{
16 Brzozowski, B.; N. Homenda; L. Roy. The value of service learning projects in preparing LIS students for public services careers in public libraries. // The Reference Librarian 53(2012), 24-40. DOI: 10.1080/02763877.2011.591690; Creel, S. L.; E. B. Pollicino. Practitioners' \& LIS students' perceptions on preparedness in the New York metropolitan area. // Education for Information 29, 1(2012), 53-69. DOI: 10.3233/EFI-2010-0911.

17 Duffus, O. Assessing UNC-Greensboro's reference interns program enhancing the employability of LIS students. // C\&RL News 78, 5(2017), 259-262. [citirano: 2018-18-08]. Dostupno na: https://crln.acrl.org/index.php/crlnews/article/view/16656/18108; Purpur, G.; J. L. Morris. The learning outcomes of mentoring Library Science students in virtual world reference: a case study. // Journal of Library \& Information Services in Distance Learning 9, 3(2015), 192-203. DOI: 10.1080/1533290X.2015.1044690.

18 Lacy, M.; A. J. Copeland. Nav. dj.; Freedman, S. Effective mentoring. // IFLA Journal 35, 2(2009), 171-182. DOI: 10.1177/0340035209105672.

19 Lacy, M.; A. J. Copeland. Nav. dj.; Lang, U. Nav. dj.

20 Lamb, C; B. Hendricks; Q. D. Galbraith. Nav. dj.; Stone, C. B.; A. M. Gruber. Nav. dj.

${ }^{21}$ Lacy, M.; A. J. Copeland. Nav. dj.; Toivonen, L.; S. Pitkakoski; P. Hynninen. Nav. dj.; Duffus, O. Nav. dj.; Henshilwood, A.; C. Sewerin; M. Spence; T. Zahradnik. Nav. dj.; Juznic, P.; B. Pymm. Students on placement: a comparative study. // New Library World 112, 5/6(2011), 248-260. DOI: $10.1108 / 03074801111136284$.

22 Juznic, P.; B. Pymm. Nav. dj.; Lacy, M.; A. J. Copeland. Nav. dj.

23 Toivonen, L.; S. Pitkakoski; P. Hynninen. dj.

24 Lamb, C; B. Hendricks; Q. D. Galbraith. Nav. dj.

25 Toivonen, L.; S. Pitkakoski; P. Hynninen. Nav. dj.
} 
U istraživanju iz 2009. godine hrvatski knjižničari i ravnatelji knjižnica ocijenili su da se na studiju teorijska znanja usvajaju bolje od onih praktičnih te da se više usvajaju stručne kompetencije (katalogizacija), dok su za svakodnevni rad u knjižnici najvažnije komunikacijske vještine jer se u knjižnicama najviše radi s korisnicima. ${ }^{26}$ Machala u kasnijem istraživanju dokazuje da je profesorima na studijima knjižničarstva u Hrvatskoj manje važan razvoj komunikacijskih vještina kod studenata, što potvrđuje ocjenu praktičara iz ranijeg istraživanja. ${ }^{27}$

Što se tiče osobina i kompetencija mentora, objavljena strana istraživanja pokazuju kako je studentima kod mentora važno da su prijateljski nastrojeni, da ih savjetuju, ali blagonaklono i bez osuđivanja ${ }^{28}$, da pružaju psihosocijalnu podršku studentu ${ }^{29}$, odnosno da pomažu, pa čak i tješe. ${ }^{30}$ Problemi koji se u odnosu mentora i studenta mogu javiti često su osobne prirode ${ }^{31}$, kao nekompatibilnost karaktera i teškoće u međusobnoj komunikaciji ${ }^{32}$, a studentima posebno smeta kada je mentor nezainteresiran ${ }^{33}$ ili nepripremljen. ${ }^{34}$

Slično stanje u Hrvatskoj pokazuje istraživanje Petr Balog, Badurine i Lisek ${ }^{35}$ koji su, doduše, istraživali stavove mladih osoba na stručnom osposobljavanju bez zasnivanja radnog odnosa (SOR), ali potvrđuju kako je mentoriranima važno da je mentor prijateljski nastrojen.

\footnotetext{
26 Machala, D. Knjižničarske kompetencije i trajna izobrazba knjižničara u Hrvatskoj: iz perspektive dionika na tržištu rada. // Cjeloživotno učenje knjižničara: ishodi učenja i fleksibilnost / urednice Aleksandra Horvat i Dijana Machala. Zagreb: Nacionalna i sveučilišna knjižnica u Zagrebu, 2009. Dostupno i na: http://www.nsk.hr/cuk/cuk.pdf [citirano: 2018-08-18]; Barbarić, A. Knjižničarske kompetencije. // Cjeloživotno učenje knjižničara : ishodi učenja i fleksibilnost / urednice Aleksandra Horvat i Dijana Machala. Zagreb : Nacionalna i sveučilišna knjižnica u Zagrebu, 2009. Dostupno i na: http://www.nsk.hr/cuk/cuk.pdf [citirano: 2018-09-26]; Lukačević; S.; K. Petr Balog. Trebamo li mijenjati svoje komunikacijske vještine?: primjer Gradske i sveučilišne knjižnice Osijek. // Vjesnik Bibliotekara Hrvatske 56, 1-2(2013). [citirano: 2018-09-26]. Dostupno na: http://www.hkdrustvo. $\mathrm{hr} / \mathrm{vjesnik-bibliotekara-hrvatske/index.php/vbh/article/view/188/183.}$

27 Machala, D. Knjižničarske kompetencije: pogled na razvoj profesije. Zagreb: Hrvatska sveučilišna naklada : Nacionalna i sveučilišna knjižnica u Zagrebu, 2015. Str. 230-231.

28 Lang, U. Nav. dj.

29 Harrington, M.; E. Marshall. Nav. dj.

30 Purpur, G.; J. L. Morris. Nav. dj.

31 Stone, C. B.; A. M. Gruber. Nav. dj.

32 Harrington, M.; E. Marshall. Nav. dj.

33 Isto.

34 Juznic, P.; B. Pymm. Nav. dj.

35 Petr Balog, K.; B. Badurina; J. Lisek. How efficient is Croatian government measure for reduction of youth unemployment: example of information and library science sector. // 3. međunarodni znanstveni simpozij Gospodarstvo Istočne Hrvatske: vizija i razvoj $=3$ rd international scientific symposium Economy of Eastern Croatia: vision and growth / urednica Anka Mašek Tonković. Osijek: Sveučilište u Osijeku, Ekonomski fakultet, 2014. Str. 660-669. Dostupno i na: https://bib. irb.hr/datoteka/698422.Petr_badurina_lisek_paper_finalno.doc [citirano: 2018-08-18].
} 


\section{Istraživanje}

Cilj ovog istraživanja bio je da se na uzorku studenata i knjižničara utvrdi postoji li, kad je riječ o važnosti i ishodima studentske prakse, razlika između stavova studenata koji su na studentskoj praksi te knjižničara/mentora koji praksu provode.

Istraživačka pitanja koja iz navedenog proizlaze jesu sljedeća: razlikuju li se stavovi studenata i knjižničara o (a) važnosti studentske prakse, (b) kompetencijama koje studenti usvajaju na praksi te (c) osobinama i kompetencijama mentora?

Postavljene su tri hipoteze:

H1: Studentska praksa važna je i korisna.

$\mathrm{H} 2$ : Studenti na praksi razvijaju generičke kompetencije.

H3: Generičke kompetencije mentora važnije su od stručnih kompetencija.

\subsection{Metodologija}

\subsubsection{Uzorak}

U istraživanju su sudjelovale dvije skupine ispitanika:

1. studenti 2. godine diplomskog studija bibliotekarstva na Odsjeku za informacijske i komunikacijske znanosti pri Filozofskom fakultetu Sveučilišta u Zagrebu (u analizi označeni slovom S i identifikacijskim brojem ispitanika)

2. knjižničari Knjižnice Filozofskog fakulteta Sveučilišta u Zagrebu (u analizi označeni slovom $\mathrm{K}$ i identifikacijskim brojem ispitanika).

Odabrano je pet studenata 2. godine diplomskog studija koji su sudjelovali na praksi u Knjižnici FFZG-a. Nisu uzeti u obzir studenti 3. godine preddiplomskog studija jer je na toj obrazovnoj razini studij multidisciplinaran i ne usmjeruje se isključivo na knjižničarstvo, kao što je slučaj na diplomskoj razini. Također, studenti 2. godine diplomskog studija moraju proći 160 sati prakse u tri do četiri knjižnice, dok studenti 3. godine preddiplomskog studija mogu izabrati i druge informacijske ustanove osim knjižnica. Četvero od pet studenata bilo je ženskog roda, $\mathrm{s}$ time da je jedan student imao 45 godina, dok ih je četvero imalo između 23 i 25 godina.

Odabir studenata po dobi i rodu ugrubo predstavlja populaciju studenata na zagrebačkom studiju knjižničarstva.

Skupinu knjižničara činilo je sedam knjižničara, među kojima su dva pomoćna knjižničara, četiri diplomirana knjižničara i jedan viši knjižničar.

Pomoćni knjižničari bili su uključeni u istraživanje jer ravnopravno s diplomiranim knjižničarima i knjižničarima u višim zvanjima sudjeluju u provođenju 
studentske prakse u Knjižnici. Svi knjižničari završili su studij knjižničarstva na FFZG-u.

Od sedam knjižničara, jedan je bio muškog roda. Četvero ih je u dobi od 30 do 40 godina, a troje u dobi od 40 do 50 godina. Jedan knjižničar ima do 5 godina radnog staža, tri knjižničara od 5 do 15 godina radnog staža, a tri od 15 do 25 godina radnog staža.

Odabir knjižničara po dobi, rodu i stažu ugrubo predstavlja knjižničarsku populaciju u Knjižnici Filozofskog fakulteta u Zagrebu.

\subsubsection{Postupak}

U ovome istraživanju korištena je kvalitativna metodologija polustrukturiranih dubinskih intervjua za studente i fokus-grupe za knjižničare.

Polustrukturirani dubinski intervju odabran je kao tehnika ispitivanja na uzorku studenata kako bi se prikupila njihova neposredna osobna iskustva. Kako su njihova iskustva s prakse različita, smatralo se da je tehnika intervjua primjerena skupini ispitanika kako bi se saznalo što više pojedinačnih iskustava.

S druge strane, za istraživanje mišljenja knjižničara odabrana je tehnika fokus-grupe jer su knjižničari stručnjaci koji su godinama mentori studentima na praksi u istoj knjižnici te su prolazili kroz vrlo slična iskustva u organizaciji i provođenju studentske prakse. Smatralo se da će zajednički razgovor tijekom fokus-grupe pridonijeti jasnijim konceptima i većoj generalizaciji.

Bez obzira na ograničenja kvalitativne metodologije (prvenstveno nemogućnost generalizacije), odabrane su dvije navedene tehnike jer je ovo prvo takvo istraživanje provedeno u Hrvatskoj te se smatralo da je važno doći do koncepata koji bi se dalje istraživali kvantitativnim metodama.

Nadalje, važno je napomenuti da se, zbog malog uzorka, rezultati ne mogu generalizirati na cijelo područje Republike Hrvatske jer su u obzir uzeti samo studenti i knjižničari sa zagrebačkog područja.

Istraživanje je provedeno u lipnju i srpnju 2018. godine.

\subsection{Rezultati i rasprava}

Vezano uz istraživačka pitanja, istraživačke tehnike oslanjale su se na tri glavne teme: važnost prakse, kompetencije studenata nakon prakse te osobine i kompetencije mentora. Citati iz transkripata navode se kako bi se potkrijepili zaključci.

\subsubsection{Važnost prakse}

Obje skupine ispitanika naglasile su važnost i korisnost studentske prakse te su navele iste razloge. 
Odgovori studenata pokazuju da studenti smatraju praksu važnom i korisnom u njihovu formalnom obrazovanju.

S1: „Ne mogu Vam opisati koliko mi je praksa bila korisna. (...) Meni je praksa baš kao trešnja na kolaču.“

S3: „Konkretno, [važno mi je] što sam konačno probala te osnovne stvari, zaduživanje i razduživanje i ovaj drugi dio s korisnicima.“

Na pitanje o važnosti prakse knjižničari su odgovorili potvrdno. Neki od knjižničara imali su studentsku praksu tijekom studija knjižničarstva, dok neki nisu. Oni koji su imali praksu na studiju izdvojili su ju kao korisnu i važnu.

K5: „Ono što si naučio vidiš u praksi, halo efekt: ahaaa, signatura tome služi!“‘

K6: „Meni je bila super praksa na Faksu i kaj smo išli po raznim knjižnicama i mogli smo steć' dojam kakve su atmosfere i kaj ljudi rade. (...) Nije ti šok kad dođeš u neku sredinu.“

Drugi, koji nisu imali praksu na studiju, napominju koliko im je nedostajala praksa na studiju ili mentor koji bi ih pratio po zapošljavanju.

K2: „Meni je bilo malo gdje sam ja to došla. (...) Mentor mi je nedostajao u svakodnevnom poslu.“

K3: „Ja nisam imala praksu za vrijeme studija i mislim da to puno fali. Sve ono što mi je falilo [kad sam se zaposlila], to kroz mentorstvo dajem studentima.“

Kroz razgovor, obje skupine ispitanika izdvojile su tri osnovna razloga zbog kojih je praksa važna i korisna: upoznavanje s knjižnicom i knjižničarskim poslom, praksa kao nadopuna studijskom programu te uvid u organizacijsku kulturu ustanove.

Studenti su prepoznali praksu kao mjesto na kojem konačno mogu vidjeti što čini posao knjižničara.

S1: „Pokazala mi je [mentorica] neke nevidljive stvari, kada vidim što vi sve radite, nisam imala dojam koliki je to obim posla."

S3: „I to sve ono što knjižničari rade i da čiste i tako...“

U istraživanju, studenti su pokazali zadovoljstvo programom prakse u pogledu činjenice da moraju proći kroz različite knjižnice jer tada mogu vidjeti različite vrste knjižnica te razmisliti gdje sebe vide u budućnosti.

S5: „Mislim da je bolje da imamo više izbora, da, hmmm, to su sve različite vrste knjižnica pa da vidimo kako koja funkcionira, gdje bismo htjeli radit' poslije.“ 
S4: „Mislim da je definitivno korisno [proći više knjižnica na praksi] jer mi ne znamo u kojoj ćemo knjižnici kasnije raditi. Mislim da je prilično korisno da imamo tu..., da imamo širok raspon knjižnica koje posjećujemo.“

Studenti se slažu oko toga da bi na praksi morali imati pravo izabrati dio poslovanja koji ih posebno zanima.

S2: „Napraviti obilazak, ali da, sad ne znam, da se pita koji su tvoji interesi. (...) Da bar vidim što me zanima, barem jedan dan.“

S3: „U jednoj sam knjižnici svih pet dana radila isto, ostavili su me samu, a bolje mi je kada sam radila više stvari."

O samom modelu prakse imali su različita mišljenja, što, čini se, ovisi o njihovim osobitostima.

S5: „Bilo mi je ok da dobijem nešto za radit'. Bilo mi je ok to kad su me stavili odmah na glavni pult... bez previše filozofiranja, bez gledanja, tako da se učim kroz rad. (...) Nije mi bilo ok neka predavanja koja sam slušao kad sam promatrao stvari onako cijeli dan, satima i onda nisam shvatio neku poantu da se tako radi na praksi.“

S4: „S obzirom na kratkoću, zapravo, vremena koje provodimo tako, zapravo čak je..., rekla bih da je korisnije uz vođenje biti uz nekog... jer samostalan rad je... pitanje rutine koja se usavrši nakon što se sve informacije imaju.“

Naposljetku, ispitanici su navodili kao važno i to da će na praksi vidjeti neke stvari koje nisu formalne, a vrlo su konkretne, tzv. „sive zone“. Tako upoznaju knjižnično poslovanje u svim vidovima.

S2: „Uvijek ćeš od knjižničara, ako ti se dovoljno otvori, i ako se uspostavi komunikacija, čuti neke stvari koje nisu tol'ko formalne, kao možda u tim [fakultetskim] skriptama i..."“

S3: „Čula sam neke konkretne situacije i nešto što oni..., nešto ono sive zone..."

S1: „Bilo je zanimljivo vidjeti kada se knjižničar javlja kao cenzor, kad on kaže ta knjiga nije za vas. Ili kada se mama javlja da li sin uči u knjižnici 002 , dal' je on tamo.“

Knjižničari su pri objašnjavanju zašto je knjižnica važna govorili iz uloge mentora, a ne više iz osobnih iskustava. Oni dijele mišljenje studenata da praksa pruža prigodu da se vidi što se u knjižnici konkretno radi, odnosno da student vidi pronalazi li se uopće u poslu knjižničara ili ne.

K3: „,... kad student dođe i kaže ja uopće nisam znao što se sve u knjižnici radi. (...) [To je] šansa da prođeš više različitih poslova, da vidiš šta ti leži, šta te zanima." 
K4: „[Vidiš] kako knjižnica iznutra funkcionira i da li ti se sviđa...“

K7: „Da student prođe sve segmente rada u knjižnici. Možemo mu reći dovoljno da dobije uvid.“

$\mathrm{Na}$ kraju, knjižničari dijele mišljenje studenata da je važno prezentirati stvarnu sliku knjižnice, u svim vidovima, i pozitivnim i onim izazovnim.

K1: „Kažeš im idealnu situaciju i realno stanje.“

K3: „Glavni ishod je da dobije širu sliku.“

Kao drugi razlog zbog kojeg je praksa važna i studenti i knjižničari naveli su da je ona nadopuna studijskom programu. Obje su skupine problematizirale raskorak između programa studija i konkretnog posla knjižničara.

S2: „Na fakultetu se nije radilo ono što je baš, ono, relevantno za posao.“

S3: „Pa zapravo, sad se ja ne mogu sjetiti niti jednog predmeta koji je bio rad u knjižnici, sve više teorijski, nije bio ovaj konkretno praktični dio posla."

S1: „Znači te situacije, ja ne znam pitati profesora: E, što bi bilo u takvoj situaciji? Jer mi ne bi palo na pamet da bi se netko tak javljao.“

Knjižničari se slažu sa studentima.

K1: „Mogu govoriti iz vremena kada sam ja studirala, to je bilo dan i noć. (...) Studij je bio vrlo krut. Studij nije pratio što se u knjižničarstvu zbiva."

K7: „U programu hrpu stvari ne rade, tipa softver u knjižnicama, KOHA, ZAKI, nemam dojam da to na predavanjima uopće dobiju.“

No ipak jedan knjižničar izdvaja poduku na studiju iz formalne obrade građe kao dovoljnu za samostalan rad u knjižnici.

K4: „Na faksu smo naučili dovoljno katalogizacije da možeš početi raditi.“

Kao treći razlog zbog kojeg je praksa važna obje skupine navode da im je ona značila mnogo po pitanju općenitog uvida u organizacijsku kulturu neke ustanove, na koji se način radi, kako postupati s kolegama, nadređenima, koja su pravila i na što je potrebno obraćati pozornost pri poslovanju. No vidljivo je kako smatraju da bi takva poduka bila primjerenija prvom zaposlenju.

S1: „, $[\mathrm{Na}$ praksi] očekujem dobiti informacije o samom radnom mjestu, o plaći..."

S3: „Nitko mi nije ništa rekao, ali mislim da bi bilo važno.“

S4: „Bilo je korisno imati nekoga tko malo shvati da imaš problema s tim, malo se makne od profesionalnog, kolege smo, nego ti stvarno pomogne oko tih detalja, ono, ova osoba već dugo radi i takav je, ovo je nova osoba pa zato ima ovakve nesuglasice i... takve sitnice." 
Na ovo su pitanje knjižničari mahom odgovarali iz vlastitog iskustva nakon zapošljavanja, navodeći koliko bi im značilo to da ih je netko uputio u svakodnevno poslovanje koje se ne tiče isključivo stručnog posla knjižničara. No ipak nisu naglašavali kako je na studentskoj praksi uloga mentora to da govori o organizacijskoj kulturi.

K1: „Administracija! To je ogroman dio posla, dok se ti uopće snađeš, ja nisam imala kog' pitat, pogotovo na Faksu, na koja vrata... dijelovi posla koji nisu vezani uz knjižničarstvo nego po pitanju rada na Fakultetu. (...) Općenito problem zaposlenika u bilo kakvoj organizaciji.“

K2: „Nitko na faksu nije spominjao taj proces kako se zaposliti, da moraš ići na stručni, što prvo moraš napraviti kada ideš tražiti posao, koji su uvjeti za knjižničare. (...) Kad sam se zaposlila [kao pomoćni knjižničar] pojma nisam imala da nemam pravo ići na stručni [za diplomiranog knjižničara].“

\subsubsection{Kompetencije koje studenti razvijaju na praksi}

Rezultati istraživanja pokazuju raskorak u stavovima studenata i knjižničara o stručnim i generičkim kompetencijama ${ }^{36}$ koje studenti razvijaju na praksi. Studenti daju prednost generičkim kompetencijama, poglavito komunikacijskim vještinama i radu s korisnicima. Knjižničari pak naglašavaju da su stručne kompetencije važnije.

Na početku, jasno se vidi stav dijela knjižničara koji misle da praksa nije mjesto na kojem studenti mogu razviti pojedine kompetencije. Mogući razlog za takav stav jest $i$ činjenica da studenti kod jednog mentora provedu maksimalno 40 sati.

K7: „Ne možemo im razviti nekakve vještine. (...) Ono što mi radimo je da ih uvedemo u naš posao i da dobiju nešto od toga."

K4: „Možemo im pokazati razvitak trendova, ali to nije vještina koju će razviti."

No daljnje istraživanje pokazuje kako i knjižničari smatraju da studenti mogu razviti neke kompetencije na praksi.

Studenti navode da je najvažnija kompetencija koju su usvojili na praksi generička kompetencija komunikacijskih vještina, što prikazuju ilustracijom neposrednog rada s ljudima. Pokazalo se da je neposredan rad s korisnicima dio knjižničarskog posla koji na studiju najmanje obrađuju te ocjenjuju da im znatno nedostaju razvijene komunikacijske vještine. Iz toga slijedi da im je rad s korisnicima najvi-

\footnotetext{
36 U ovome dijelu istraživanja za referentnu točku u raspravi o kompetencijama uzet je popis stručnih i generičkih kompetencija iz Machala, D. Knjižničarske kompetencije i trajna izobrazba knjižničara u Hrvatskoj : iz perspektive dionika na tržištu rada. // Cjeloživotno učenje knjižničara : ishodi učenja i fleksibilnost / urednice Aleksandra Horvat i Dijana Machala. Zagreb : Nacionalna i sveučilišna knjižnica u Zagrebu, 2009. Str. 104-105.
} 
še stresan. Ističu da su u razgovoru s mentorima dobili mnogo informacija o okolnostima koje se na studiju ne obrađuju te da su vidjeli kako se snaći u izazovnim i zahtjevnim odnosima s korisnicima.

S2: „Drugačije je kad vidiš korisnike.“

S3: „Bilo mi je zanimljivo slušati iskustva od knjižničara na primjer kada dođu neki neugodni korisnici, ili kako postupiti kad..., ono, s uzimanjem osobne ili nešto, jer će to sve biti situacije koje će se dogoditi, a mi na faksu nismo ništa čuli o tome.“

S4: „Dolaze ljudi, posebno zbog lektire i tu ima zanimljivih slučajeva gdje ima različitih, mmm, pristupa roditelja knjižničarima. Taj pristup gdje se morate snalaziti s kim pričate [s roditeljem ili djetetom].“

Zanimljivo, knjižničari nisu navodili da je na praksi važno razvijati komunikacijske vještine. Ipak, jedan knjižničar navodi kako se kroz cijelu praksu trudi da studenti imaju uvid u korisničke potrebe, ali ne navodi da to čini kroz neposredan rad s korisnicima, nego kroz sve dijelove poslovanja.

$\mathrm{K} 1$ : „Ja se trudim da cijelo vrijeme u glavi imaju korisnika.“

Od generičkih kompetencija, knjižničari navode da je na praksi vrlo važno razvijanje kritičkih i samokritičkih sposobnosti te da se tomu trude podučiti studente.

K3: „[Važno je] da shvate da su knjižnice nekakve ustanove koje djeluju u nekom kontekstu koji je dosta nepredvidiv i ne baš jednostavan.“

Što se tiče usvajanja stručnih kompetencija, vidi se blagi raskorak u stavovima studenata i knjižničara vezano uz pitanje koje stručne kompetencije smatraju važnima. Knjižničari su češće nego studenti navodili stručne kompetencije kao važnije te su među njima posebno izdvojili znanje i sposobnost formalne obrade, uz navođenje da je važno pokazati im formalnu obradu u određenom knjižničnom programu, što doprinosi i razvoju stručne kompetencije sposobnosti upravljanja i uporabe informacijskih tehnologija, poglavito u integriranim knjižničnim računalnim sustavima (KOHA, ZAKI, METEL...). Tek je jedna studentica izdvojila katalogizaciju.

K7: „Važno im je vidjeti katalogizaciju, druge stvari su im interesantne, ali ono što očekuju je katalogizacija. I tome se vesele.“

S2: „Tamo sam radila, pokazala mi je [mentorica] na Metel sustavu katalogizaciju tih zvučnih knjiga, na cd-ima im je uglavnom građa.“

S druge strane, studenti ističu kao važne kompetencije učinkovitog pružanja informacija za potrebe korisnika, vještine pretraživanja i vrednovanja informacija, vještine uporabe informacijskih pomagala i izvora te sposobnost poučavanja korisnika. 
S5: „Najviše rad s korisnicima, toga apsolutno nema na fakultetu, čak niti u teoriji, ima kolegij na Fakultetu, ali se on više bavi vrstama upita i ne znam, vrstama kakvi su ti korisnici, jesu li ovako obrazovani, onako obrazovani, a ne bavi se konkretno njima ličnostima u žurbi ili ličnostima kojima nešto očajnički treba.“

S4: „Najveća novost je bila međuknjižnična posudba, pogotovo kol'ko je stvar njezinog [mentoričinog] iskustva rada i iskustva pronalaska građe u tim knjižnicama preko tih kataloga, preko tih sustava, iskustvo s tim koliko treba vremena pojedinoj knjižnici da pripremi, da pošalje, da dođe do Hrvatske, mmm, i iskustva zapravo s korisnicima koliko je netko zapravo spreman platiti, odnosno koliko netko ne zna što može jeftinije pa je na njoj da posudi jeftiniju verziju za koju korisnik niti ne zna da postoji ta mogućnost."

S1: „Informacijska pismenost je ono što korisnici najviše traže i to se vidi na praksi.“

Valja napomenuti da ispitani knjižničari, iako rade u fakultetskoj knjižnici, nisu spominjali razvoj gore navedenih kompetencija kroz rješavanje zahtjevnih informacijskih upita koji se u takvoj knjižnici, zbog profila korisnika, mogu očekivati.

K7: ,Nisam im pokazivala način na koji mogu odgovoriti, ali sam im pokazala upite i objasnim im kako to funkcionira."

K2: ,[Odgovaranja na upite] ima najmanje na praksi jer nam ne dolazi puno korisnika.“

Obje skupine ispitanika smatraju važnim razvijanje stručne kompetencije znanja i primjene izgradnje i upravljanja zbirkama.

S4: „Bilo je informacija vezano uz nabavu knjiga što je također novo. (...) Bilo je zanimljivo saznati da nakladnici šalju svoje ljude u knjižnice i da oni od tih knjiga moraju odabrati što im je zanimljivo, a ono što nije se vrati."

K1: [Pokazujem im] sam taj proces [nabava i obrada knjige]. (...) Da dobije sliku što to konkretno znači.“

Zbog poznavanja knjižničarske zajednice i okruženja u kojima knjižnice djeluju, knjižničari navode da treba kod studenata na praksi razvijati i stručne kompetencije razumijevanja zakonskih i etičkih okvira te vještinu i sposobnost javnog komuniciranja.

K3: „Govorim im o standardima, da su ih knjižničari počeli rano razvijati. (...) Bitna su neka osnovna znanja, a onda se lako prilagođava. Da kroz obrazovanje dobivaju osnove osnova, a sve drugo se jako brzo mijenja. Pričam im što se malo šire dešava." 
K5: „Napominjem negativnu sliku knjižničara u javnosti i unutar institucije. (...) Dio prakse je da mi sebe dajemo na van! Sami smo sebi PR.“

Obje skupine također navode da je vještina organizacije raznih aktivnosti i događanja važna. Ta se vještina može smatrati i stručnom (sposobnost organiziranja programa iz kulture) i generičkom kompetencijom (organizacijske sposobnosti) stavi li se više naglasak na poznavanje potreba za organiziranjem određenih programa ili na osobnu sposobnost organizacije. Studenti navode da je i to jedan dio poslovanja knjižnice o kojem nisu previše govorili na studiju, a na praksi su vidjeli koliko je to velik dio knjižničnog poslovanja.

S3: „Knjižničari u gradskim stalno rade razne radionice i to mi je bilo zanimljivo jer to na faksu nisam baš vidjela."

S4: „S njom [mentoricom] sam dosta radila i saznala sam neke, 'ajmo reć', interne informacije o organizaciji događaja, o problemima tada, osobito kad ste jedna gradska knjižnica i to u centru dosta je problem kome dajete mogućnost organiziranja događaja u vašem prostoru.“

S3: „Rad s djecom mi je bilo zanimljivo čuti, to možemo dobiti na praksi bolje."

Knjižničari se slažu da je vještina organizacija raznih aktivnosti i događanja važna jer je njihova organizacija velik dio knjižničnog poslovanja.

K4: „Oni nauče tipične knjižničarske poslove, a svi mi imamo neka posebna zaduženja, izložbe... to nije nešto što su naučili na Fakultetu, dobiju dojam da su knjižnice življe sredine od slike koje bi mogli dobiti na faksu.“

K2: „Ja sam je uključila da odabere naslove za izložbu, bila je oduševljena. Bilo joj je jako drago, dobila je dojam da mislim o njoj jako pozitivno, da joj dajem odgovoran posao.“

\subsubsection{Osobine i kompetencije mentora}

Rezultati potvrđuju hipotezu kako je važnije da mentor ima razvijene generičke vještine nego one stručne. Obje skupine navode da su stručne kompetencije važne, ali zadržavaju naglasak na vrlo razvijenim generičkim vještinama, poglavito komunikacijskim vještinama (interpersonalnim $i$ intrapersonalnim vještinama), $i$ to prvenstveno komunikacijskim vještinama mentora u odnosu na studente na praksi.

U ovome dijelu istraživanja na fokus-grupi knjižničara koristila se tehnika prikupljanja atributa pomoću kartica, odnosno svaki knjižničar trebao je napisati tri osnovne osobine ili vještine mentora.

Ispitanici iz obiju skupina smatrali su da je strpljenje najvažnija komunikacijska vještina koju bi mentor trebao posjedovati. 
S1: „Važno mi je da je [mentor] komunikativan i da mi ukaže na stvari koje ne znam da pitam. Komunikativan, pristupačan. Strpljenje. Imali su razumijevanja. (...) Jedno bez drugog ne ide [struka i komunikacijske vještine], ali moraju biti strpljivi.“

S3: „Važnije mi je da je strpljiv i ono samo postupanje. (...) Super mi je bilo da je kolega danas, ono, ponovio što smo u utorak radili.“

K3: „Ne snage, ne snage, strpljenja [smijeh].“

Knjižničari još navode da je važno pokazati razvijene komunikacijske vještine prema korisnicima.

K4: „Mislim da ono što je važno je, recimo, da smo mi savjesni u svom radu i da smo jako fer i ljubazni prema korisnicima.“”

Uz strpljenje, ispitanici u obje skupine navodili su da je važan ugodan nastup. Knjižničari su navodili sljedeće atribute: blagonaklon, ljubazan, komunikativan, sluša potrebe studenata.

S2: „I da, komunikacija, da nije ono: ah, došla si mi na praksu, što ću sad... ono, prijateljski pristup.“

S2: „Atmosfera je bila, ah, tu si, ajmo radit, ta neka otvorenost prema studentima. To mi je bilo super. Može se, mmm, i pitanja postavit', i dobit' nekakve odgovore, sve nekako što te zanima, zasad je to što se tiče komunikacije bilo super."

I studenti i knjižničari izrijekom su naveli kako je potrebno da mentor bude strog, ali strpljiv (studenti), odnosno pravedan (knjižničari).

S4: „Tu bi čak prije bila strog, ali strpljiv.“

Obje skupine navode da je vrlo važna prilagodljivost mentora.

S5: „Da je fleksibilan po pitanju [vremena i] drugih obaveza jer se, ipak, praksa ne plaća.“

Obje su skupine prepoznale kako je važno da mentori imaju razvijene organizacijske sposobnosti i vještine upravljanja. Studenti to potkrepljuju željom da mentor bude pripremljen, a knjižničari prepoznaju potrebu da kao mentori budu dobri organizatori, motivirajući i vješti u prenošenju znanja.

S4: „Inače ima tih situacija kada se pokušava zapravo, imate voditeljicu koja zna da je vaš mentor i imate situaciju kada želite proširiti malo, a ne samo da s njom radite i stavi vas u neki drugi odjel, a ta osoba se s time snalazi da nekome treba prenijeti znanje, a nije bila pripremljena. (...) Mislim to su sad odluke zašto vas je stavio da radite s njime, a, onda taj element da svi se snalazimo sad odjednom i ja koja bi trebala 
učiti i netko 'ko bi me trebao mentorirat' to područje a nije ni bio pripremljen na to, nego ad hoc, odjedanput.“

K7: „Organizator. (...) Organizacija svega, znači, prakse, vremena, tog materijala."

K5: „Moraš bit jako dobar u svom poslu, ali i jako dobar u prenošenju informacija.“

Nadalje, knjižničari se slažu da je za uspjeh studentske prakse važna mentorova želja za uspjehom, odnosno motivacija da bude mentor.

K1: „I ono što mislim da je jako važno, da bi prvo trebao biti motiviran za mentoriranje, da to ne može biti nešto što je nametnuto."

K4: ,Jer mislim da može biti velika šteta ako oni [studenti] dobiju dojam, vidi, ovima se niš ne da.“

K3: „Slažem se s tim da nisu svi za mentore i to nema veze sa stručnošću, jednostavno nemaju ljudi svi te sposobnosti.“

Što se tiče stručnih vještina, dojam je da je i studentima i knjižničarima važno da je mentor stručan, ali su generičke vještine mentora važnije za uspješno provođenje prakse.

Studenti navode da im je važno vidjeti širinu znanja kod mentora, dakle ne samo stručno znanje u knjižničarstvu nego i široko opće znanje te veliko radno iskustvo. Iskazuju potrebu za time da mentor bude upoznat s poslovanjem cijele knjižnice.

S2: „Fora mi je što je svatko završio još nešto, neko, neku studijsku grupu.(...) Meni je super dok se vidi neka stručnost, neko zanimanje za to, da nije da je samo u svom polju, nego da je zanimaju i druge stvari, da je upoznat sa svime što [knjižnica] radi, ali [...] ipak da je neka širina u pitanju.“

S4: „Definitivno je korisno da je... jedan osobni faktor koji ipak daje neko osobno iskustvo rada jer su ipak mentori ljudi koji imaju godine iskustva pa tako neka kombinacija ne samo rada kao takvog nego i nekih osobnih iskustava vezanih uz promjene koje je ta osoba vidjela na tom radnom mjestu.“

Knjižničari se slažu kako je važno da mentor poznaje kontekst u kojem radi i iz kojeg dolazi student.

K4: „Mislim da bi bilo dobro da je upoznat s programom studija, trenutnim, da znamo s čim uopće, ono, raspolažemo, kog susrećemo.“

K4: „I da je upoznat s našim, recimo, knjižničnim sustavom u kojem funkcioniramo." 
Knjižničari su tijekom ispitivanja prvenstveno govorili o generičkim vještinama. Na izravan upit o važnosti stručnih vještina, knjižničari iskazuju da im je to važno.

K4: „Ovo stručno znanje smo skroz zanemarili [smijeh].

K1: „To [da je mentor stručan] se podrazumijeva.“

K3: ,Zapravo sam mislila neki autoritet, autoritet, ne sigurno ne da si nafrljen ili ono, nego upravo to neko svoje znanje i stručnost da je autoritet i da te oni tako doživljavaju."

Slažu se da je stručnost mentora važna, ali ne i presudna u provođenju studentske prakse.

K7: ,Ja mislim da bi mentor trebao biti vrhunski stručnjak, ako je on mentor, na onom, kako se ono zove, stručnom osposobljavanju ili mentor za diplomski rad, razumiješ, a ne'ko 'ko je (...) kod tebe 40 sati i trebaš ga uvest' u posao koji, nadamo se dobro radiš, onda je to dovoljno. Onda ne trebaš biti vrhunski stručnjak u katalogizaciji.“

K5 „Njima se prenose neka osnovna znanja, pokazuješ dio svog posla, ne pokazuješ sve, manji segment svog poslovanja, pa ako ćeš opet biti prestručan, izgubit ćeš ih u svemu tome.“

Na kraju knjižničari zaključuju da su generičke vještine ipak važnije.

K5: „Ove [generičke vještine] su važnije.“

K2: „Za praksu da.“

Očigledno je da i studenti i knjižničari shvaćaju kolika ograničenja studentska praksa ima po pitanju dužine trajanja i opsežnosti znanja koje bi mentori trebali prenijeti. No u tom prenošenju znanja važno je da su mentori prvenstveno osobe koje mogu svoje znanje prenijeti na smiren i ugodan način.

\section{Zaključak}

Rezultatima ovog istraživanja potvrđene su hipoteze H1: Studentska praksa je važna i korisna te H3: Generičke kompetencije mentora važnije su od stručnih, pri čemu nije utvrđena razlika u stavovima između dviju skupina ispitanika. Hipoteza H2: Studenti na praksi razvijaju generičke kompetencije potvrđena je djelomično, a utvrđena je i razlika u stavovima studenata i knjižničara. Studenti potvrđuju H2, dok ju stavovi knjižničara negiraju.

Iz rezultata ovog istraživanja vidljivo je kako i studenti i knjižničari prepoznaju praksu kao neophodnu u formalnom obrazovanju knjižničara. Na praksi se student prvi put susreće s praktičnim radom i konačno može svoja teorijska znanja i kompetencije stečene na studiju primijeniti u stvarnom okruženju. Kako bi praksa 
bila što uspješnija, nužno je da mentor ima razvijene komunikacijske vještine i želju za uspjehom. Mentor svojim generičkim kompetencijama stvara sigurno i poticajno okruženje u kojem se studenti ugodno osjećaju te lakše mogu razviti potrebne kompetencije. Nažalost, rezultati istraživanja Lukačevića, Petr Balog i Pađen Farkaš pokazuju da su u hrvatskim knjižnicama još uvijek rijetki tečajevi za poučavanje koji će knjižničare podučiti komunikacijskim metodama i tehnikama. ${ }^{37}$ Stoga bi bilo važno omogućiti mentorima da se osnaže i obrazuju u području komunikacijskih vještina kako bi što bolje mogli prenijeti svoje znanje. Dobar je primjer Slovenija, gdje je mentorima omogućeno obrazovati se kako bi bili što kvalitetniji. ${ }^{38}$

Utvrđena razlika u stavovima studenata i knjižničara prema vrsti kompetencija koje studenti razvijaju na praksi pokazuje da su studenti svjesni nedostatnosti studijskog programa. Studenti, prema svom kazivanju, na studiju nemaju prigode razvijati generičku kompetenciju komunikacijskih vještina i uviđaju da im ta kompetencija nedostaje za posao knjižničara. Studenti smatraju da je rad s korisnicima iznimno važan i čest te da im ujedno nedostaje osnovna kompetencija za uspješno obavljanje toga posla. Knjižničari ne smatraju da je razvijanje komunikacijskih vještina najbitnije za studente na praksi, što je suprotno nalazima Machalinih istraživanja. ${ }^{39,40}$ Takav stav može se tumačiti metodološkim ograničenjem ovoga istraživanja, odnosno time da knjižničari dolaze iz samo jedne vrste knjižnica (iz fakultetske knjižnice), pa ga je potrebno ponovno provjeriti daljnjim istraživanjima bez navedenoga metodološkog ograničenja.

Ovo je istraživanje prvo istraživanje takve vrste u Republici Hrvatskoj. Rezultati istraživanja važni su zbog osnovnog uvida u problematiku te se mogu smatrati polazišnom točkom za daljnja istraživanja kojima bi se postigla generalizacija. No bez obzira na metodološka ograničenja, može se zaključiti da je knjižnica važan i nezaobilazan partner Odsjeku za informacijske i komunikacijske znanosti u provođenju studijskog programa. Raskorak između teorijskog znanja usvojenog na studiju i praktičnog rada u knjižnicama ne treba se smatrati negativnim. Dapače, snažnijom suradnjom između Odsjeka i knjižnica, u kojoj bi se jasno odredilo koje će kompetencije studenti na praksi razvijati, knjižnice bi s osposobljenim knjižničarima postale još važniji partner Odsjeku u formalnom obrazovanju knjižničara.

37 Lukačević, S.; K. Petr Balog; D. Pađen Farkaš. Asertivnost i komunikacija u knjižničnom okruženju : primjer Gradske i sveučilišne knjižnice Osijek. // Libellarium 9, 1(2016). Str. 108. DOI: http://dx.doi.org/10.15291/libellarium.v9i1.245.

38 Juznic, P.; B. Pymm. Nav. dj.

39 Machala, D. Knjižničarske kompetenije i trajna izobrazba knjižničara u Hrvatskoj. Nav. dj.

40 Machala, D. Knjižničarske kompetencije : pogled na razvoj profesije. Nav. dj. 


\section{LITERATURA}

Barbarić, A. Knjižničarske kompetencije. // Cjeloživotno učenje knjižničara: ishodi učenja i fleksibilnost / urednice Aleksandra Horvat i Dijana Machala. Zagreb : Nacionalna i sveučilišna knjižnica u Zagrebu, 2009. Dostupno i na: http://www.nsk.hr/ cuk/cuk.pdf [citirano: 2018-09-26].

Brzozowski, B.; N. Homenda; L. Roy. The value of service learning projects in preparing LIS students for public services careers in public libraries. // The Reference Librarian 53(2012), 24-40. DOI: 10.1080/02763877.2011.591690.

Campbell-Meier, J.; L. K. Hussey. Learning outcomes for student workers? Perceived mentoring and the gap between training and educating library student workers. // The Journal of Academic Librarianship 42, 6(2016), 745-749. DOI: 10.1016/j.acalib.2016.06.007.

Creel, S. L.; E. B. Pollicino. Practitioners' \& LIS students' perceptions on preparedness in the New York metropolitan area. // Education for Information 29, 1(2012), 53-69. DOI: 10.3233/EFI-2010-0911

Duffus, O. Assessing UNC-Greensboro's reference interns program enhancing the employability of LIS students. // C\&RL News 78, 5(2017), 259-262. [citirano: 2018-1808]. Dostupno na: https://crln.acrl.org/index.php/crlnews/article/view/16656/18108.

Filozofski fakultet Sveučilišta u Zagrebu. Odluka od 27. studenog 2017. Klasa: 11204/17-03/29, Urbroj: 3804-460-17-2.

Freedman, S. Effective mentoring. // IFLA Journal 35, 2(2009), 171-182. DOI: $10.1177 / 0340035209105672$

Harrington, M.; E. Marshall. Analyses of mentoring expectations, activities, and support in Canadian academic libraries. // College \& Research Libraries 75(2014), 763-790. DOI: $10.5860 / \mathrm{crl} .75 .6 .763$.

Henshilwood, A.; C. Sewerin; M. Spence; T. Zahradnik. Librarians: the next generation: mentorship at the University of Toronto. // 122nd ASEE Annual Conference \& Exposition, Seattle, USA, June 14-17, 2015. DOI: 10.18260/p.24433.

Ho, K.; P. Lo; D. Chiu; E. Wei San Kong; J. Chao-chen Chen; Q. Zhou; Y. Xu; S. Dalsgard. Intrinsic vs. extrinsic motivations of Master of Library and Information Science students: a cross-cultural comparative study. // Journal of Librarianship and Information Science 50, 2(2017), 141-156. DOI: 10.1177/0961000616664564.

Hussey, L. K.; J. Campbell-Meier. Is there a mentoring culture within the LIS profession? // Journal of Library Administration 57, 5(2017), 500-516. DOI: 10.1080/01930826.2017.1326723.

Juznic, P.; B. Pymm. Students on placement: a comparative study. // New Library World 112, 5/6(2011), 248-260. DOI: 10.1108/03074801111136284. 
Lacy, M.; A. J. Copeland. The role of mentorship programs in LIS education and in professional development. // Journal of Education for Library and Information Science 54, 2(2013), 135-146. [citirano: 2018-06-23]. Dostupno na: http://www.jstor.org/ stable/43686941.

Lamb, C; B. Hendricks; Q. D. Galbraith. Growing the profession: mentoring undergraduates for librarianship. // College \& Undergraduate Libraries 22, 2(2015), 123-148. DOI: 10.1080/10691316.2015.1035181.

Lang, U. Being a mentor: [izlaganje]. // IFLA WLIC 2015 - Cape Town, South Africa - Satellite Meeting : Continuing Professional Development and Workplace Learning Section. Taking Charge of your LIS Career : Personal Strategies, Institutional Programs, Strong Libraries, 12-14 August 2015, City of Cape Town, South Africa. [citirano: 2018-08-18]. Dostupno na: http://library.ifla.org/id/eprint/1940.

Lukačević; S.; K. Petr Balog. Trebamo li mijenjati svoje komunikacijske vještine?: primjer Gradske i sveučilišne knjižnice Osijek. // Vjesnik Bibliotekara Hrvatske 56, 1-2(2013). [citirano: 2018-09-26]. Dostupno na: http://www.hkdrustvo.hr/vjesnik-bibliotekara-hrvatske/index.php/vbh/article/view/188/183.

Lukačević, S.; K. Petr Balog; D. Pađen Farkaš. Asertivnost i komunikacija u knjižničnom okruženju: primjer Gradske i sveučilišne knjižnice Osijek. // Libellarium 9, 1(2016), 89-110. DOI: http://dx.doi.org/10.15291/libellarium.v9i1.245.

Machala, D. Knjižničarske kompetencije : pogled na razvoj profesije. Zagreb: Hrvatska sveučilišna naklada: Nacionalna i sveučilišna knjižnica u Zagrebu, 2015.

Machala, D. Knjižničarske kompetencije i trajna izobrazba knjižničara u Hrvatskoj: iz perspektive dionika na tržištu rada. // Cjeloživotno učenje knjižničara : ishodi učenja i fleksibilnost / urednice Aleksandra Horvat i Dijana Machala. Zagreb: Nacionalna i sveučilišna knjižnica u Zagrebu, 2009. Dostupno i na: http://www.nsk.hr/cuk/cuk. pdf [citirano: 2018-08-18].

Petr Balog, K.; B. Badurina; J. Lisek. How efficient is Croatian government measure for reduction of youth unemployment: example of information and library science sector. // 3. međunarodni znanstveni simpozij Gospodarstvo Istočne Hrvatske: vizija i razvoj $=3$ rd international scientific symposium Economy of Eastern Croatia: vision and growth / urednica Anka Mašek Tonković. Osijek : Sveučilište u Osijeku, Ekonomski fakultet, 2014. Str. 660-669. Dostupno i na: https://bib.irb.hr/datoteka/698422.Petr_badurina_lisek_paper_finalno.doc [citirano: 2018-08-18].

Purpur, G.; J. L. Morris. The learning outcomes of mentoring Library Science students in virtual world reference: a case study. // Journal of Library \& Information Services in Distance Learning 9, 3(2015), 192-203. DOI: 10.1080/1533290X.2015.1044690.

Pymm, B.; P. Juznic. The view from industry: LIS students on placement. // Library Review 63, 8/9(2014), 606-623. DOI: 10.1108/LR-01-2014-0013. 
Stone, C. B.; A. M. Gruber. Ambitious student seeks valuable internship: will you mentor me? // LOEX Conference Proceedings 2011, 3(2013), 11-14. [citirano: 2018-0712]. Dostupno na: http://commons.emich.edu/loexconf2011/3.

Studentska praksa - diplomski studij. [citirano: 2018-08-18]. Dostupno na: http://inf. ffzg.unizg.hr/index.php/hr/studij/diplomski-studij/studentska-praksa.

Studentska praksa - preddiplomski studij. [citirano: 2018-08-18]. Dostupno na: http:// inf.ffzg.unizg.hr/index.php/hr/studij/preddiplomski-studij/studentska-praksa.

Toivonen, L.; S. Pitkakoski; P. Hynninen. Mentoring LIS students during their internships: case study : [izlaganje] // IFLA WLIC 2017 - Wrocław, Poland - Libraries. Solidarity. Society. School Libraries, Education and Training and Continuing Professional Development and Workplace Learning. [citirano: 2018-08-18]. Dostupno na: http://library.ifla.org/id/eprint/1645. 
